\title{
Content Marketing Decisions for Effective Internal Communication
}

\begin{abstract}
The paper focuses on the assumption that new marketing and communication concepts, including content marketing, provide new opportunities for internal communication. The problem solved in this paper argues how content marketing decisions can contribute to effective internal communication. Based on scientific literature analysis, a theoretical-hypothetical model of the content marketing decisions' contribution to the effective internal communication is presented.
\end{abstract}

Keywords: content marketing, internal communication, effective internal communication, content marketing decisions.

Šis straipsnis remiasi prielaida, jog naujos marketingo ir komunikacijos koncepcijos suteikia naujas galimybes vidinei komunikacijai. Straipsnyje analizuojama, kaip turinio marketingo sprendimai gali prisidèti prie efektyvios vidinès komunikacijos. Remiantis atlikta mokslinès literatūros analize, pateikiamas teorinis-hipotetinis turinio marketingo sprendimų indèlio ị vidinès komunikacijos efektyvumą modelis.

Raktiniai žodžiai: turinio marketingas, vidinè komunikacija, vidinès komunikacijos efektyvumas, turinio marketingo sprendimai

\section{Introduction}

It is not a secret that today business all over the world is very challenging. As K. Rajhans (2012) notes, in order to stay profitable in the highly challenging and competitive global market economy, all the factors of production should be wisely managed. The constant change brought by the world globalization, forces organizations to apply methods that organize the means that lead the company to obtain better performance and make full use of all its resources; without it, an environment of instability and uncertainty among its members is created (Martinez, Hurtado, 2018).
Many authors (White, Vanc, Stafford, 2010; Almonaitiene, Zukauskas, 2015; Diaconu, Oancea, Brinzea, 2016; Martinez, Hurtado, 2018) admit that organizations must constantly communicate with current and potential stakeholders so that to offer high quality products and services, to establish value and to facilitate their access to customers. It is well known that employees are one of the main groups of company stakeholders. Due to this, effective internal communication plays an important role in improving the working environment and performance of business (Rajhans, 2012; Almonaitiene, Zukauskas, 2015; Zerfass et al., 2015). Moreover, the 
results of various studies (Ruizalba et al., 2014; Saad et al., 2015; Park, Tran, 2018) revealed that there is a positive connection between effective internal communication and external marketing effectiveness. Unfortunately, internal communication, in today's organizations has become far more complex and varied (Men, 2014; Sebastião et al., 2017).

Until quite recently, internal communication received little attention from marketing experts and researchers since their focus of attention was on external communication. However, internal communication is now of great opportunity for many organizations, and theorists are re-examining internal communication in the light of developments such as employee engagement (Welch, 2011; Karanges et al., 2015; Zerfass et al., 2015). Digitization has brought extensive changes to businesses communication. The complex nature of the digital economy is characterized by various functions and provides global access to knowledge and information (Ukko, Saunila, Rantala, 2016). The increasing importance of information created preconditions for content marketing to become a separate marketing paradigm (Gagnon, 2014; Holliman, Rowley, 2014; Hanafizadeh, Yarmohammadi, 2015), which are based on creation and distribution of valuable content for the customer. According to researchers (Gagnon, 2014; Jaakonmäki et al., 2017) this type of content can be used as a tool to increase the effectiveness of different marketing activities.

Therefore, discussions about the content marketing benefits and application to a different kind of business show the importance of knowing how quality content may affect internal customers in different communication channels and how it can be used for internal communication. Therefore, the scientific problem solved in the paper is presented as follows: how content marketing decisions can contribute to effective internal communication? Correspondingly, the aim of the present paper is to develop a theoretical-hypothetical model of content marketing decisions for effective internal communication.

Research methods. Seeking to provide a substantial theoretical background for further studies on internal communication effectiveness, a theoretical analysis and synthesis is provided. In the first stage of research, literature review has been carried out. In order to ascertain the contribution of content marketing decisions to the effective internal communication scholarly studies have been analysed in following fields: internal communication in general (White et al., 2010; Rajhans, 2012; Yeomans, FitzPatrick, 2017; and others), features of effective internal communication (Marques, 2010; Ruck, Welch, 2012; Mazzei, 2014; Martinez, Hurtado, 2018; and others), content marketing concept (Pulizzi, 2012; Gagnon, 2014; Holliman, Rowley, 2014; and others) and content marketing decisions (Halevi, O’Hanlon, 2016; Järvinen, Taiminen, 2016; Kose, Sert, 2017; and others).

Following this stage of research, the perceived information was evaluated, compared and summarized using systematic analysis. The insights of particular analysis provide a basis for the creation of a theoretical-hypothetical model. The theoretical-hypothetical model has been formed applying the synthesis method. 


\section{Effective internal communication}

Internal communication is the term used to describe an organization's managed communication system, where employees are regarded as an internal public or stakeholder group (Verčič, Verčič, Sriramesh, 2012). Other terms used for this communication system are 'employee communication' (Nakamura, Umeki and Kato, 2017), 'organizational communication' (Marques, 2010) and 'internal marketing' (Ahmed, Rafiq, 2003). K. Réka and A. Borza (2012) summarized the internal communication concept which includes:

- Sending and receiving messages that create and maintain a system of consciously coordinated activities;

- The tools by which organizational activities can be unified, and its members can understand their own role;

- The means through which personnel establishes a coherent social reality and identity, as well as the leadership style and power relations in the organization.

Despite the varied terminology, many authors (Welch, Jackson, 2007; White et al., 2010; Nakamura et al., 2017; Martinez, Hurtado, 2018; and others) agree that internal communication is one of the key factors which leads to business success. Accordingly, there are many provisions expressing the advantages of effective internal communication.

First, in the information age, an organization's assets include the knowledge and interrelationships of its people. As B. Ouirke (quoted from Welch and Jackson, 2007) marked, it is internal communication business to take the input of information, using the creative and intellectual assets of its people to process it in order to produce value. Therefore, it could be stated that internal communication is one of the main processes by which business can create this kind of value. From a value creation perspective, which is close to several researchers' view (Ruck, Welch, 2012; Zerfass et al., 2015; Belasen and Belasen, 2018), effective internal communication can create value not only for employees, but also for the business itself or a final customer. C. White et al. (2010) explain this provision by saying that effective internal communication can enhance corporate reputation and credibility because employees are viewed as particularly credible sources by external stakeholders. Accordingly, corporate communication as a community of practice is no longer the exclusive domain of public relation or marketing departments, which traditionally have focused on external stakeholders. Based on A. T. Belasen and A. R. Belasen (2018), other functional areas within the organization play important roles in both internal and external communication while also influencing decision-making, strategic communication planning, and policy implementation.

Secondly, effective internal communication can be treated as the solution of business problems. L. A. M. Martinez and S. R. F. Hurtado (2018) widely described this point of view by saying that internal communication in organizations is one of the fundamental axes to face each of the challenges related to market expansion, globalization, quality, and competitiveness. Faced with these business challenges, organizations must not only be focused on the profit, production, and administration but also communication as the main axis of business action; because this 
constitutes the central system of all the processes of an organization. Likewise, from this perspective, it can be said that communication is established as a condition and strategic tool for the processes of the relations of the organization with the environment, and the interaction with the internal personnel. Furthermore, as K. Ruck and M. Welch (2012) stressed, organizations need to evaluate and improve communication especially in increasingly difficult economic pressures.

The third provision highlighting the importance of internal communication in an employee engagement perspective (Welch, Jackson, 2007; White et al., 2010; Rajhans, 2012; Yeomans, FitzPatrick, 2017). Even the management concept of employee engagement suggests that 'building two-way, trusting relationships with internal publics, with the goal of improving organizational effectiveness', is a strategic concern for leaders and practitioners (Yeomans, FitzPatrick, 2017). Due to this reason, the objectives of encouraging employees to act as advocates, getting them to stay and to work harder are often grouped together under the heading of employee engagement; a subject that is of increasing interest in academic and practitioner discussions over the past years (Welch, 2011; Johansson, 2015). C. White et al. (2010) noticed that numerous studies have linked internal communication and the degree to which employees are informed to job satisfaction and performance. For example, K. Réka and A. Borza (2012) marked, that communicators have an important role in maintaining trust in the workplace. On the other hand, internal communication is inextricably linked to supporting an organization's need to effectively communicate information about important changes - for example, a merger with another company, a re-branding or the introduction of a new product (Yeomans and FitzPatrick, 2017). In theory (Yeomans and FitzPatrick, 2017; Belasen and Belasen, 2018), employees should be among the first to know about changes so that they are able to see their own role in the particular situation. However, L. Yeomans and L. FitzPatrick (2017) highlights, that 21 st century - a period which reflects an interest in the concepts of 'engagement' and 'consultation' with employees against the backdrop of factors including a lack of trust in management and an 'engagement deficit', changing labor practices and transformational communication technologies.

Considering different advantages of internal communication, the remaining important aspect is its effectiveness. According to H. Nakamura et al. (2017), noneffective internal communication causes the decrease in motivation, the deficiency in internal feedback, the relegation of human talent, the difficulty in a corporate strategy and the lack of knowledge of the organization chart, it is for this should highlight the importance of effective communication inside the organization. Nerveless, the competitive advantage of effective internal communication comes not only from the obvious benefits of employee satisfaction and productivity (Zerfass et al., 2015; Belasen, Belasen, 2018). C. White et al. (2010) come to conclude that it also comes from the positive contributions that well-informed employees can make to a company's external public relations efforts. Depends on whether and how employees get information, they can be an organization's best ambassadors or loudest critics. 
Literature review (Ruizalba et al., 2014; Men, 2014; Martinez, Hurtado, 2018; Park, Tran, 2018) revealed that there is no unanimous approach to the concept of effective internal communication or key performance indicators of it. Although, during theoretical analysis, emerged a few features which describes and effectiveness of internal communication. These features could be divided into two related groups: characteristics of effective internal communication and capabilities of effective internal communication. These groups answer questions what kind of internal communication should be and what could be achieved with this kind of communication.

One group of researchers (Marques, 2010; Ruck, Welch, 2012; Martinez, Hurtado, 2018) pay more attention to characteristics of effective internal communication:

1. Timely delivery
2. Clarity
3. Accuracy
4. Credibility
5. Eligibility
6. Responsibility
7. Conciseness
8. Professionalism
9. Sincerity.

The authors of this paper take the view that these nine characteristics can be treated as the basis for all internal communication initiatives which seeks for effectiveness. The second group of researchers (Welch, Jackson, 2007; Mazzei, 2014; Yeomans, FitzPatrick, 2017) associate effective internal communication with its capabilities. They distinguish six objectives, which could be achieved by using effective internal communication:

1.Contributing to internal relationships characterized by employee engagement.
2. Promoting a positive sense of belonging in employees.

3. Developing their awareness of environmental change.

4. Developing employees' understanding of the organization aims.

5.Ensuring employees' awareness about organization expectations.

6. Promoting external advocacy.

Considering the advantages of effective internal communication, which have been discussed before, it could be seen that these capabilities are related too.

Apart from these two groups, there are several suggestions which should be taken into account as well. Various studies in internal communication field (Marques, 2010; Rajhans, 2012; Almonaitiene, $\mathrm{Zu}$ kauskas, 2015; Martinez, Hurtado, 2018; and others) reveal guidelines for effective internal communication: Effective communication should involve more than top-down communication; A process of effective internal communication should include the creation of a means that allows the correct feedback; Communication specialist should consider the fact that effective internal communication is not just information; Communication should be delivered in a responsible format given its content.

Overall, the effective management of internal communication, in turn, is responsible for managing, planning and evaluating the information flows that concern both the external and internal client, in relation to the objectives of the company and the sector to which it belongs (Martinez, Hurtado, 2018). Furthermore, an organization's managed internal communication may include a variety of channels and activities, but it is still not clear how to use it properly. An 
effective management of internal communication requires broader approach and application of modern decisions. Therefore, content marketing, one of the newest marketing parading, can meet these requirements.

\section{Content marketing concept}

In the developed and dynamic world, organizations have realized the importance of digital marketing (Khan, Siddiqui, 2013; Järvinen, Karjaluoto, 2015). According to T. Lopes and J. Machado (2014), there is an increasing trend towards developing business with the support of digital platforms, and thus for improving the internal and external communication system. Hence, there is always a continued need for making even this easy way of communication better and better to improve whole marketing processes of a company (Kose, Sert, 2017).

More and more researchers (Gagnon, 2014; Holliman, Rowley, 2014; Hanafizadeh, Yarmohammadi, 2015) focus on the content and information quality as one of the main aspect determining the attractiveness of communication products to the consumer that afterward can affect consumer confidence, satisfaction and loyalty. This provides a strong incentive for the content marketing, new marketing trend, development.

We detect a few types of content marketing definitions: from one of the earliest definition as "Content marketing attracts potential consumers and increases their engagement and empowerment through the creation, dissemination and sharing of free content, relevant, meaningful, valuable and able to inspire confidence in existing and potential customers" given by S. Kucuk and S. Krishnamurthy (2007), to the one of the newest "The content marketing is sharing the valuable information regarding the products and brands to attract others to participate in purchasing activities that create the engagement relationship between consumers and the companies" given by N. S. Ahmad, R. Musa and M. H. R. Harun (2016). Obviously, a decade of content marketing development did not dramatically affect the essence of its concept. Wider analysis of different content marketing definitions (Repovienè, 2017) allows noticing that the main goal of implementing content marketing is to create and distribute valuable and consistent content to the target audience in

Table 1. Content marketing concept

\begin{tabular}{|l|l|l|}
\hline \multicolumn{1}{|c|}{ Provisions } & \multicolumn{1}{|c|}{ Objectives } & \multicolumn{1}{c|}{ Decisions } \\
\hline - Value creation through the content & - Customer engagement & - On the content type \\
- Content marketing is a dialogue & - Value for customer & - On the distribution \\
- Content marketing focuses on delivering & - Conversions & - On the content formats \\
information & - Brand awareness & - On the content elements \\
- Content marketing is based on high- & - Competitive advantage \\
quality content & - Relationship with customers & \\
- Content marketing is a marathon, not & & \\
a sprint. & & \\
\hline
\end{tabular}

Source: created by the authors based on R. Rose and J. Pullizzi (2011), E. Gagnon (2014), G. Halevi and R. O'Hanlon (2016), J. Järvinen and H. Taiminen (2016), U. Kose and S. Sert (2017), and et al. 
order to stipulate the profitable consumer action. Depending on this goal, the main task is creation of relevant and useful content, which meets customer specific needs (Järvinen, Taiminen, 2016). Generally speaking, content marketing concept is based on the assumption that when enterprises provide valuable information for the customer, they can expect a useful customer response. The detailed aspects of content marketing are given in Table 1 .

Content marketing is inseparable from basic provisions which are distinguished by several authors (Gagnon, 2014; Holliman, Rowley, 2014; Hanafizadeh, Yarmohammadi, 2015, Ahmad et al., 2016; and others). These provisions highlight the importance of quality information, value creation, two-way communication and strategic view. Furthermore, by using a content-based marketing strategy companies are able to achieve specific objectives (Rose, Pullizzi, 2011; Abel, 2014; Halevi, O’Hanlon, 2016), which overlap general marketing goals. In terms of content marketing implementation, theoretical analysis revealed four groups of content marketing decisions. Taking into account the aim of this paper, it is necessary to briefly review these groups.

Decisions on the content type answer the question 'What kind of content we will create?' (Chasser, Wolfe, 2010; Gagnon, 2014; Abel, 2014; Schuinanii, Wangenheim, Groene, 2014). In an ideal situation, content should include seven characteristics: relevance, informativeness, reliability, value, uniqueness, emotions, and intelligence. However, previous studies (see Pažeraitè, Repovienè, 2016; Repovienè, 2017) show that it is difficult to combine all these characteristics, so companies need to decide on what to focus their attention on.
Regardless of the content type, content should be interchangeable and communicated across different platforms and channels (Halevi, O’Hanlon, 2016). Decisions on the distribution channels answer the question 'Where our content will be published?'(Berger, Milkman, 2012; Azad, Mohsen, AliAkbar, 2016). As R. Stokes (2013) noted, the selection of distribution channels is a significant process that equates to the content creation. Even that content marketing can be applied in various platforms (Pažèraitè, Repovienè, 2016; Jaakonmäki, Müller, Brocke, 2017), the variety of possibilities requires a strategic view on it as well.

The next group of content marketing decisions is related to content formats. Decisions on the content formats answer to the question 'Which content formats we will use?' (Holliman, Rowley, 2014; Kose, Sert, 2017; Jaakonmäki et al., 2017). From a general perspective, it is possible to say that content marketing can be in many different types of formats, for example as: articles, posts, video, photos, infographics, banners, gifs, e-mail newsletters, etc. Nowadays, the results of existing studies about the effectiveness of different formats (Ashley, Tuten, 2015; Kim, Spiller, Hettche, 2015) have shown that the success of the format depends on particular situations.

The last group of decisions answer to the question 'Which elements related with the content we will use?' (Kose, Sert, 2017; Leung, Chan, 2017; Jaakonmäki et al., 2017). Undoubtedly, these decisions are linked to the chosen format, and usually include practical decisions for the use of elements like action buttons, site links, hashtags, emoji, etc. Unfortunately, there are not many studies in this field. 
The authors of this paper believe that content marketing can improve effectiveness of various communication activities and contribute to the business success. The entire content marketing concept or its separate decisions in internal communication may be used as well. Therefore, the next part of this paper deals with a contribution of a theoretical-hypothetical model of content marketing decisions to the effective internal communication.

\section{Content marketing decisions for the effective internal communication}

Based on the systematic analysis of internal communication (Ahmed, Rafiq, 2003; Verčič et al., 2012; Réka, Borza, 2012; Nakamura et al., 2017, Martinez, Hurtado, 2018; et al.), features of effective internal communication (Marques, 2010; Ruck, Welch, 2012; Mazzei, 2014; Yeomans, FitzPatrick, 2017; Martinez, Hurtado, 2018), the concept of content-based marketing (Pulizzi, 2012; Gagnon, 2014; Holliman, Rowley, 2014; Ahmad et al., 2016; and others) as well as its application through specific decisions (Stokes, 2013; Schuinanii et al., 2014, Halevi, O'Hanlon, 2016; Kose, Sert, 2017; Jaakonmäki et al., 2017; and others), it can be noted that there are interconnections between these components. This fact allows making the assumption that interaction between the mentioned components can be an effective communication approach. Therefore, the authors of this article provide a theoretical-hypothetical model of content marketing decisions for the effective internal communication (Figure 1).

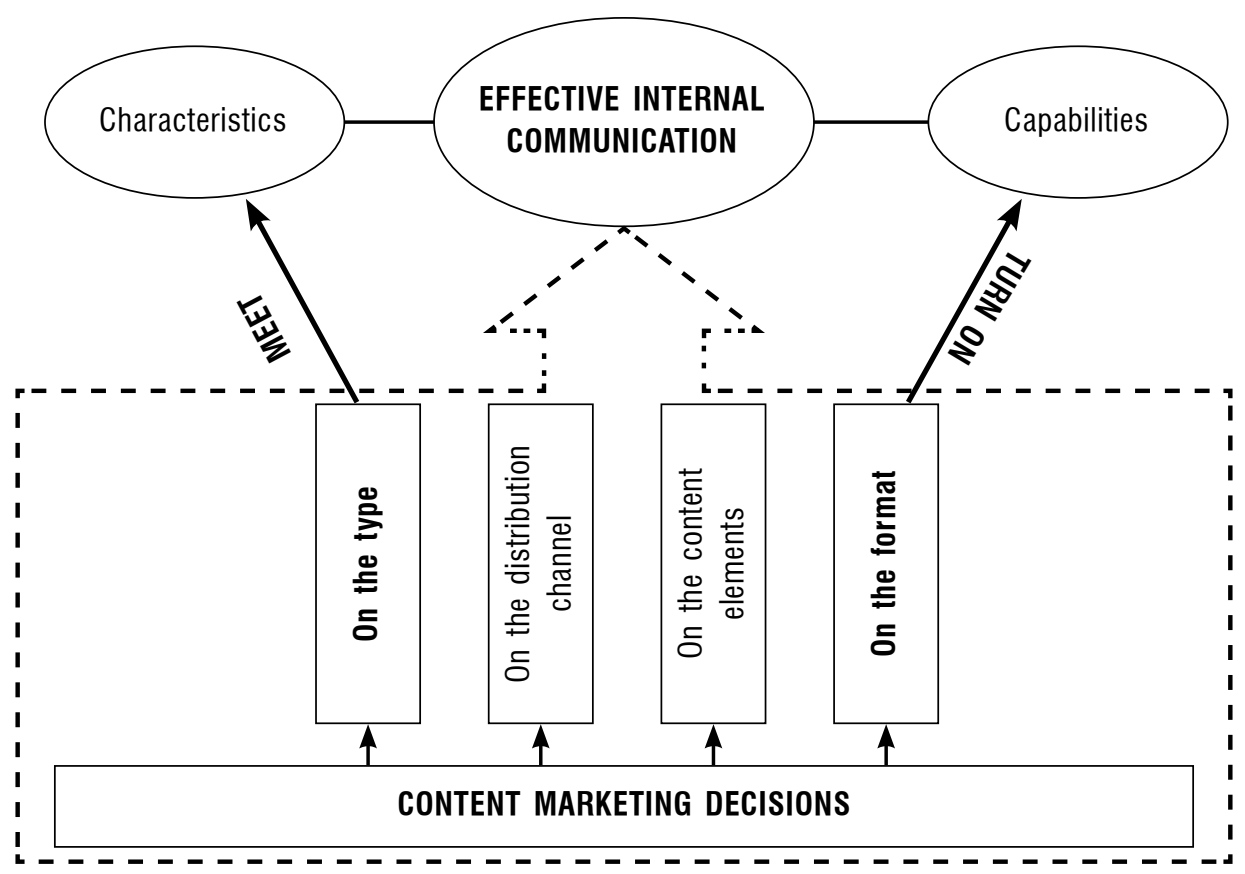

Fig. 1. A theoretical-hypothetical model of content marketing decisions for the effective internal communication 
In the broader context, content marketing can help to increase the effectiveness of internal communication. As the presented literature review shows, content marketing provisions (Gagnon, 2014; Holliman, Rowley, 2014; Hanafizadeh, Yarmohammadi, 2015, Ahmad et al., 2016; and others) illustrate the main aspects and features of effective internal communication (Ruck, Welch, 2012; Martinez, Hurtado, 2018; Park, Tran, 2018). The focus on value through the content can help to achieve the main advantages of effective internal communication, especially the value creation for internal and external customers. Evidently, that focus on information delivery reflects the main function of internal communication too. Furthermore, provisions, which are related to two-way communication and strategic view, also contribute to aspirations of internal communication.

Despite these general contributions, the comparison of different content marketing decisions and effective internal communication give some hypothetical insights. Due to their features, application conditions and importance of different content marketing decisions, two decisions are highlighted as more suitable in order to increase the effectiveness of internal communication. Considering this, two hypotheses have been formulated.

The first hypothesis proposes the positive contribution of decisions to the content type. Thus, a content marketing decision on the content type meets characteristics of the effective internal communication. For instance, communication which uses relevant content, meets the requirements for time delivery and eligibility. Whereas, reliable content meets such characteristics as creditability and responsibility. In general, all seven content types are closely related to the nine characteristics of the effective internal communication.

Moving forward, the second hypothesis proposes the positive contribution of decisions to the content format. Content marketing decisions on the format turn on the capabilities of effective internal communication. Therefore, responsibly selected content formats contribute to the achievement of internal communication objectives. As an example, short video, one of the most attractive content format, can help to promote in employees a positive sense of belonging. While using the infographic turn on the capability to develop employees' understanding of the organization aims. Certainly, contribution of particular decisions depends not only on the format, but on the type of the content as well.

Unfortunately, the theoretical background did not allow determining a direct link between the next two types of content marketing decisions and effective internal communication. The limitations of internal communication channels restrict the distribution of content. The lack of evidence about the effect of separate content elements does not provide a direct precondition for internal communication effectiveness. Nevertheless, the authors believe that the complex of content marketing decisions could be applied and used in practice for to increase the effectiveness of internal communication.

Obviously, this model is still a theoretical-hypothetical one and the formulated hypothesis needs to be verified. Seeking to prepare the model for the future 
development and practical applications, it is necessary to expand the field of research. The authors have the ambition to test the formulated hypothesis in order to prepare the model for the next stage of scientific and practical development. Later, the verified model could be developed with the aim to expand research field using separate content marketing decisions, measuring the contribution level or conducting research in different cases.

\section{Conclusions}

Analysis of the internal communication concept allows describing internal communication as a function responsible for communication among participants within an organization. The continued attention of researchers on the importance of internal communication as an object of research, revealed the main advantages of the effective internal communication information delivery, value creation, solution of business problems, and satisfaction of employees.

Various scholars admitted that noneffective internal communication causes various problems, which affect business results. Regardless of this fact, there is no consensus on what the effective internal communication means. Literature analysis suggests a conclusion that effective internal communication can be described through the two group of features as: characteristics and capabilities. The importance of these features and the challenging environment leads to a search for new ways to communicate.

One of the newest marketing concepts is content marketing. Content marketing involves the creation and distribution of valuable content in order to get the desired response. Furthermore, it is based on provisions which highlight the importance of quality information, value creation, two-way communication, and strategic view. The theoretical background also allows distinguishing four types of content marketing decisions on: type, distribution channel, content element, and the format.

Having evaluated and compared the perceived information about the features of the effective internal communication, the concept of content-based marketing and particular content marketing decisions, it can be noted that there are interconnections between these components. Considering this, a theoretical-hypothetical model of the content marketing decisions' contribution to the effective internal communication is provided. The comprehensive theoretical analysis has shown that two types of content marketing decisions, namely, decisions on the type and on the format, contribute to the effective internal communication.

The research findings and limitations offer opportunities for further research. This paper has focused on the contribution of content marketing decisions to the effective internal communication in a theoretical way. For proper practical development of it, it is necessary to expand the field of research and verify the theoretical-hypothetical model. Therefore, the provided model could be developed in a perspective of contribution level assessment, combination of decision types, different business sectors or specific content marketing decisions. 


\section{References}

1. Abel, S. (2014). Why Content Marketers Need Intelligent Content // Econtent, October. Internet access: http://www.econtentmag.com/ Articles/Column/Flexing-Your-Content/WhyContent-Marketers-Need-Intelligent-Content-99670.htm [accessed April 2, 2018].

2. Ahmad, N. S., Musa, R., Harun, M. H. M. (2016). The Impact of Social Media Content Marketing (SMCM) towards Brand Health // Procedia Economics and Finance. Vol. 37, pp. 331-336. doi: 10.1016/S2212-5671(16)30133-2

3. Ahmed, P. K., Rafiq, M. (2003). Internal Marketing Issues and Challenges // European Journal of Marketing. Vol. 37, No. 9, pp. 1177-1186. doi: 10.1108/03090560310498813.

4. Almonaitiene, J., Zukauskas, D. (2015). Managerial Communication and Related Variables in a Food Retail Chain // Social Sciences, Vol. 88, No. 2, pp. 24-37. doi: 10.5755/j01.ss.88.2.12735.

5. Ashley, C., Tuten, T. (2015). Creative Strategies in Social Media Marketing: An Exploratory Study of Branded Social Content and Consumer Engagement // Psychology \& Marketing. Vol. 32, No. 1, pp. 15-27. doi: 10.1002/ mar.20761.

6. Azad, N., AliAkbar, S., Zomorodian, S. (2016). Factors Stimulating Content Marketing // Management Science Letters. Vol. 6, No. 2, pp. 109114. doi: 10.5267/j.msl.2016.1.002.

7. Belasen, A. T., Belasen, A. R. (2018). Integrated Corporate Communication: A Competing Values Perspective. Internet access: https:// www.researchgate.net/profile/Ariel_Belasen/ publication/322232298_Integrated_Corporate_Communication_A_Competing_Values_ Perspective/links/5a4cfe7b0f7e9b8284c4af0b/ Integrated-Corporate-Communication-ACompeting-Values-Perspective.pdf [accessed April 12, 2018].

8. Berger, J., Milkman, K. (2012). What Makes online Content Viral? // Journal of Marketing Research. Vol. 49, No. 2., pp. 192-205. doi: http:// dx.doi.org/10.1509/jmr.10.0353.

9. Chasser, A., Wolfe, J. (2010). Brand Rewired: Connecting Branding, Creativity, and Intellectual Property Strategy Hardcover. - San Francisco: Willey.

10. Diaconu, M., Oancea, O., Brinzea, M. (2016). Integrated Marketing Communication, Instrument of Modern Organizations Development in Terms of Sustainability // Ecoforum Journal. Vol. 5, No. 2, p. 270-277. Internet access: http:// www.ecoforumjournal.ro/index.php/eco/article/viewFile/417/264 [accessed April 16, 2018].

11. Gagnon, E. (2014). Goodbye, B2B Brand Marketing: Developing Content-Based Marketing Programs for the Post-Marketing Era // International Management Review. Vol. 10, No. 2., p. 68-71. Internet access: http://scholarspress. us/journals/IMR/pdf/IMR-2-2014/v10n2-art7. pdf [accessed April 2, 2018].

12. Halevi, G., O’Hanlon, R. (2016). Creating Content Marketing for Libraries // Journal of the Medical Library Association: JMLA. Vol. 104, No. 4, pp. 342-345. doi: 10.3163/1536-5050.104.4.019.

13. Hanafizadeh, P., Yarmohammadi, M., (2015). An Integrated Conceptualization of Content in an Information Society // Information Development. Vol. 10, No. 1, pp. 1-10. doi: 10.1177/0266666915572926.

14. Heide, M., Simonsson, C. (2011). Putting Coworkers in the Limelight: New Challenges for Communication Professionals // International Journal of Strategic Communication. Vol. 5, No. 4, pp. 201-220. doi: 10.1080/1553118X.2011.605777.

15. Holliman, G., Rowley, J. (2014). Business to Business Digital Content Marketing: Marketers Perceptions of Best Practice // Journal of Research in Interactive Marketing. Vol. 8, No. 4, pp. 269-293. doi: 10.1108/JRIM-02-2014-0013.

16. Jaakonmäki, R., Müller, O., Brocke, J. (2017). The Impact of Content, Context, and Creator on User Engagement in Social Media Marketing // Proceedings of the 50th Hawaii International Conference on System Sciences, pp. 1152-1160. doi: 10.24251/HICSS.2017.136.

17. Järvinen, J., Karjaluoto, H., (2015). The Use of Web Analytics for Digital Marketing Performance Measurement // Industrial Marketing Management. Vol. 50, pp. 117-127. doi: 10.1016/j.indmarman.2015.04.009.

18. Järvinen, J., Taiminen, H. (2016). Harnessing Marketing Automation for B2B Content Marketing // Industrial Marketing Management. Vol. 54, pp. 164-175. doi: 10.1016/j. indmarman.2015.07.002.

19. Johansson, C. (2015). Empowering Employees through Communicative Leadership. - Braga, Portugal: CECS.

20. Karanges, E., Beatson, A., Johnston, K., Lings, I. (2014). Optimizing Employee Engagement with Internal Communication: A Social 
Exchange Perspective // Journal of Business Marketing Management. Vol. 7, No. 2, pp. 329353. Internet access: https://eprints.qut.edu. au/73156/3/73156.pdf [accessed April 16, 2018].

21. Khan, F., Siddiqui, K. (2013). The Importance of Digital Marketing. An Exploratory Study to Find the Perception and Effectiveness of Digital Marketing amongst the Marketing Professionals in Pakistan // Journal of Information Systems \& Operations Management, Vol. 7, No. 2, pp. 1219. Internet access: http:// www.rebe.rau.ro/RePEc/rau/jisomg/WI13/ JISOM-WI13-A2.pdf [accessed April 12, 2018].

22. Kim, D. H., Spiller, L., Hettche, M. (2015). Analyzing Media Types and Content Orientations in Facebook for Global Brands // Journal of Research in Interactive Marketing. Vol. 9, No. 1, pp. 4-30. doi: 10.1108/JRIM-05-2014-0023.

23. Kose, U., Sert, S. (2017). Improving Content Marketing Processes with the Approaches by Artificial Intelligence // Eforum. Vol. 6, No. 1, pp. 1-8. Internet access: https://arxiv.org/ftp/ arxiv/papers/1704/1704.02114.pdf [accessed April 12, 2018].

24. Kucuk, S. U., Krishnamurthy, S. (2007). An Analysis of Consumer Power on the Internet // Technovation. Vol. 27, No. 1-2, pp. 47-56. doi: 10.1016/j.technovation.2006.05.002.

25. Leung, C. H., Chan, W. T. Y. (2017). Using Emoji Effectively in Marketing: An Empirical Study // Journal of Digital \& Social Media Marketing. Vol. 5, No. 1, pp. 76-95. Internet access: http:// www./2017/00000005/00000001/art00007 [accessed April 10, 2018].

26. Lopes, T., Machado, J. (2014). How can a Corporate Brand (of Higher Education) Benefit from Social Networks in its Internal Communication Strategy? The Case of Catholic University of Portugal Porto. Internet access: https:// repositorio.ucp.pt/handle/10400.14/21142 [accessed April 12, 2018].

27. Marques (2010). Enhancing the Quality of Organizational Communication: A Presentation of Reflection-based Criteria // Journal of Communication Management. Vol. 14, No. 1, pp. 47-58. doi: 10.1108/13632541011017807.

28. Martinez, L. A. M., Hurtado, S. R. F. (2018). Internal Communication Issues in the Firms: Does It Affect the Productivity? // Review of European Studies. Vol. 10, No. 2, pp. 1-13. doi: 10.5539/res.v10n2p1.

29. Mazzei, A. (2014). Internal Communication for Employee Enablement: Strategies in American and Italian Companies // Corporate Communications: An International Journal. Vol. 19, No. 1, p. 82-95. doi: 10.1108/CCIJ-08-2012-0060.

30. Men, L. R. (2014). Strategic Internal Communication: Transformational Leadership, communication channels, and employee satisfaction // Management Communication Quarterly, Vol. 28, No. 2, p. 264-284. doi: 10.1177/0893318914524536.

31. Nakamura, H., Umeki, H., Kato, T. (2017). Importance of Communication and Knowledge of Disasters in Community-based Disasterprevention Meetings // Safety Science. Vol. 99, pp. 235-243. doi: 10.1016/j.ssci.2016.08.024.

32. Park, J. H., Tran, T. B. H. (2018). Internal Marketing, Employee Customer-oriented Behaviors, and Customer Behavioral Responses // Psychology \& Marketing. Vol. 35, Issue 6, pp. 412-426. doi: 10.1002/mar.21095.

33. Pažèraite, A., Repoviené, R. (2016). Content Marketing Elements Influence on Search Advertisement Effectiveness: Theoretical Background and Practical Insights // Management of Organizations: Systematic Research. Vol. 75, pp. 97109. doi: 10.7220/MOST.2335.8750.2016.75.7.

34. Pulizzi, J. (2012). The Rise of Storytelling as the New Marketing // Publishing Research Quarterly. Vol. 28, No. (2), pp. 116-123. doi: 10.1007/ s12109-012-9264-5.

35. Rajhans, K. (2012). Effective Organizational Communication: A Key to Employee Motivation and Performance // Interscience Management Review. Vol. 2, No. 2, pp. 81-85. Internet access: https://pdfs.semanticscholar.org/d74f/ ce848669ba68f7a8929a9ec1a108758a98b9.pdf [accessed April 12, 2018].

36. Réka, K., Borza, A. (2012). Internal and External Communication within Cultural Organizations // Management \& Marketing. Challenges for the Knowledge Society. Vol. 7, No. 4, pp. 613630. Internet access: http:// www.managementmarketing.ro/pdf/ articole/287.pdf [accessed April 12, 2018].

37. Repoviene, R. (2017). Role of Content Marketing in a Value Creation for Customer Context: Theoretical Analysis // International Journal of Global Business Management and Research, Vol. 6 (2), pp. 37-48. Internet access: http:// www.rajalakshmi.org/ijgbmr/downloads/IJGBMRAug17.pdf [accessed April 3, 2018].

38. Repoviene, R. (2017). Turinio marketingo taikymas paieškos sistemose esančiose reklamose: Google AdWords atvejis // Aukštujų mokyklų 
vaidmuo visuomenejje: iššǔkiai, tendencijos ir perspektyvos, Vol. 6, No. 1, pp. 228-235. Internet access: http://alytauskolegija.lt/wp content/ uploads/2017/12/2017_konferencijos_leidinys. pdf [accessed March 3, 2018].

39. Rose, R., Pulizzi, J. (2011). Managing Content Marketing. - Cleveland, OH: CMI Books.

40. Ruck, K., Welch, M. (2012). Valuing Internal Communication; Management and Employee Perspectives // Public Relations Review. Vol. 38, No. 2, pp. 294-302. doi: 10.1016/j. pubrev.2011.12.016.

41. Ruizalba, J. L., Bermúdez-González, G., Rodríguez-Molina, M. A., Blanca, M. J. (2014). Internal Market Orientation: An Empirical Research in Hotel Sector // International Journal of Hospitality Management. Vol. 38, pp. 11-19. doi: 10.1016/j.ijhm.2013.12.002.

42. Saad, N. M., Hassan, S. H., Shya, L. M. (2015). Revisiting the Relationship between Internal Marketing and External Marketing: The Role of Customer Orientation // The Journal of Developing Areas. Vol. 49, No.3, pp. 249-262. doi: 10.1353/jda.2015.0165.

43. Schuinanii, J., Wangenheim, F., Groene, N. (2014). Targeted Online Advertising: Using Reciprocity Appeals to Increase Acceptance among Users of Free Web Services // Journal of Marketing. Vol. 78, No. 1, pp. 59-75. doi: http:// dx.doi.org/10.1509/jm.11.0316.

44. Sebastião, S. P., Zulato, G., Trindade, A. D. (2017). Internal Communication and Organisational Culture: The Management Interplay in the View of the Portuguese Communication Consultant // Public Relations Review, Vol. 43, No. 4, pp. 863-871.

45. Stokes, R. (2013). EMarketing: The Essential Guide to Digital Marketing. Internet access: http://www.redandyellow.co.za/wpcontent/uploads/emarketing_textbook_download.pdf [accessed March 3, 2018].

46. Ukko, J., Saunila, M. ir Rantala, T. (2016). From Customer Value to Customer Wisdom - Managing and Measuring Customer Value Cocreation in Digital Service Systems. Internet access: https://www.researchgate.net/profile/ Paula_Guerra5/publication/310060218_Reviving_DIY_The_importance_of_do_it_yourself_.
to_the_Portuguese_alternative_rock_scene/ links/582873fe08ae950ace6fae49/RevivingDIY-The-importance-of-do-it-yourselfto-the-Portuguese-alternative-rock-scene. pdf\#page $=466$ [accessed April 3, 2018].

47. Verčič, A. T., Verčič, D., Sriramesh, K. (2012). Internal Communication: Definition, Parameters, and the Future // Public Relations Review. Vol. 38, No. 2, pp. 223-230. doi: 10.1016/j. pubrev.2011.12.019.

48. Welch, M. (2011). The Evolution of the Employee Engagement Concept: Communication Implications // Corporate Communications: An International Journal. Vol. 16, No. 4, pp. 328346. doi: $10.1108 / 13563281111186968$.

49. Welch, M., Jackson, P. R. (2007). Rethinking Internal Communication: A Stakeholder Approach // Corporate Communications: An International Journal. Vol. 12, No. 2, pp. 177-198. doi: 10.1108/13563280710744847.

50. White, C., Vanc, A., Stafford, G. (2010). Internal Communication, Information Satisfaction, and Sense of Community: The Effect of Personal Influence // Journal of Public Relations Research. Vol. 22, No. 1, pp. 65-84. doi: $10.1080 / 10627260903170985$.

51. Yeomans, L. (2008). “... it's a general meeting, it's not for us..." Internal Communication and Organizational Learning - an Interpretive Approach // Corporate Communications: An International Journal. Vol. 13, No. 3, pp. 271-286. doi: 10.1108/13563280810893652.

52. Yeomans, L., FitzPatrick, L. (2017). Exploring Public Relations. 4th ed. - United Kingdom: Pearson Education.

53. Zerfass, A., Verčič, D., Verhoeven, P., Moreno, A., Tench, R. (2015). European Communication Monitor 2015: Excellence in Strategic Communication: Creating Communication Value through Listening, Messaging and Measurement: Results of a Survey in 41 Countries. Internet access: https://dare.uva.nl/ search?identifier $=4318 \mathrm{~d} 1 \mathrm{ae}-\mathrm{effb}-430 \mathrm{f}-\mathrm{b} 784$ 25ab99d84f66 [accessed April 16, 2018].

The paper submitted: April 27, 2018 Prepared for publication: June 29, 2018 


\section{Aušra PAŽÉRAITÉ, Rūta REPOVIENĖ TURINIO MARKETINGO SPRENDIMAI EFEKTYVIAI VIDINEI KOMUNIKACIJAI}

S a n tra u k a

Dinamiška ir iššūkių verslo aplinka išryškina išmintingo valdymo, įvairiapusio įmonès išteklių panaudojimo ir veiklų efektyvumo poreiki. Priešingu atveju, nereaguojant $\mathfrak{i}$ ši poreikį, sukuriama verslo aplinka, pasižyminti nestabilumu ir neapibrèžtumu, o tai lemia pralaimèjimą konkurencinèje kovoje. Vidiné komunikacija yra viena pagrindinių priemonių, padedančių skleisti informaciją organizacijos viduje ir supažindinti jos narius su esamomis problemomis, tikslais arba pokyčiais. Nors mokslininkai ir komunikacijos ekspertai pripažįsta informacijos sklaidos ir vidinès komunikacijos svarbą, šio proceso efektyvumui didinti yra skiriama nepakankamai dèmesio. Atsiradus naujiems ir efektyvesniems būdams komunikuoti su visomis suinteresuotomis šalimis, tarp jų ir organizacijos nariais, ši dèmesio stoka tampa ypač aktuali. Skiriant dèmesị naujų komunikacijos ir marketingo koncepcijų nagrinèjimui bei pritaikymui, sudaromos sąlygos plèsti žinias, tobulinti vidinès komunikacijos procesus ir žengti koją kojon su naujausiomis marketingo ir komunikacijos tendencijomis.

Atsižvelgiant it turinio marketingo koncepcijos esmę, ryškèja prielaida, jog ši marketingo rūšis gali būti naudinga vidinei komunikacijai, suteikiant naujų galimybių jos efektyvumui didinti. Pirmiausia, turinio marketingo sprendimų pritaikymas vidinès komunikacijos procesuose gali padeti padidinti efektyvumą ir sèkmingai pasiekti tikslus. Be to, tai gali prisideti prie skirtingų vidinès komunikacijos priemonių poveikio organizacijos nariams didinimo. Siekiant nustatyti, kaip turinio marketingo sprendimai prisideda prie efektyvios vidinès komunikacijos, šiame straipsnyje pateikiami atliktos teorinès analizès rezultatai.

Pirmoje darbo dalyje autorių dèmesys skiriamas vidinei komunikacijai ir jos efektyvumui. Mokslinès literatūros apžvalga apima vidinès komunikacijos sampratos, funkcijų bei pranašumų analizę. Atsižvelgiant $\mathfrak{i}$ darbo tikslą, darbe taip pat pateikiami efektyvios vidinès komunikacijos aspektai. Atlikta analizè leido šiuos aspektus išskirti i dvi pagrindines grupes, remiantis efektyvios vidinès komunikacijos charakteristikomis bei gebejjimais.

Tolesne darbo dalis skirta turiniu paremto marketingo, kaip naujos marketingo rūšies, analizei: straipsnyje pateikiamas turinio marketingo apibrèžimas, pagrindinès nuostatos, tikslai ir sprendimai. Išsami teorinè analizè atskleidè, jog turinio marketingo koncepcija remiasi aukštos kokybès turiniu, dvikrypte komunikacija ir strateginiu požiūriu. Dèka panašių tikslų, nuostatų, charakteristikų ir vertybių ižvelgiamos sąsajos tarp turinio marketingo koncepcijos ir vidinès komunikacijos. Dèl šios priežasties turinio marketingo praktinis pritaikymas, besiremiantis atskiromis sprendimų grupèmis, gali potencialai prisidèti prie vidinès komunikacijos efektyvumo gerinimo.

Galiausiai straipsnyje pateikiamas teorinis-hipotetinis turinio marketingo sprendimų efektyviai vidinei komunikacijai modelis. Šis modelis apibendrina aukščiau minètus žingsnius ir perteikia teigiamus turinio marketingo sprendimų pritaikymo vidinejje komunikacijoje aspektus.

Darbo pabaigoje pateikiamos išvados, praktinès jžzvalgos ir ateities tyrimų galimybès. 